\title{
Commission on the Status of Women
}

\section{Fiftieth session}

27 February - 10 March 2006

Item 3 of the provisional agenda*

Follow-up to the Fourth World Conference on Women and to the special session of the General Assembly entitled

"Women 2000: gender equality, development and peace for the twenty-first century"

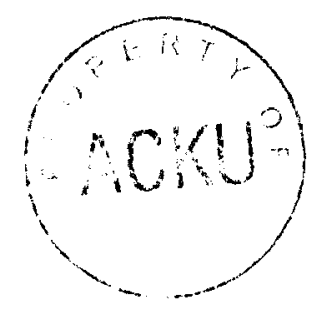

\section{The situation of women and girls in Afghanistan**}

Summary

The present report provides an update of the situation of women and girls in A fighanistan in 2005, in response to Economic and Social Council resolution 2005/8. with particular focus on the electoral process, efforts to promote and protect the rights of women and girls and social and economic reconstruction and rehabilitation. It includes information on activities undertaken by the United Nations system in support of the work of the Government of Afghanistan for the advancement of women and gender equality. While significant gains have been made by Afghan women and girls, including in the legal, political and educational areas, progress is not felt in all parts of the country and the gender development indicators remain among the worst in the world. Continuous and widespread incidents of human rights violations and violence against women call for prompt and enhanced action by both the Government and the international community.

\footnotetext{
* E/CN 6/2006/1
}

** The submission of the present report was delayed due 10 the need for further consultations with relevant United Nations entities

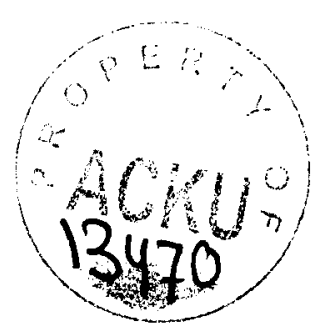




\section{Contents}

Paragraphs ras

I. Introduction

$1-3 \quad 3$

II. Intergovemmental processes.

$4-9 \quad 3$

III. Elections

$10-18 \quad 4$

IV. Activities of the Ministry of Women's Affairs

$19-26 \quad 6$

V. Violence against women and access to justice

$27-46 \quad 7$

A. Violence against women

$27-34 \quad 7$

B. Human rights, transitional justice and the rule of law.

$35-46 \quad 9$

VI. Socral and economic reconstruction and rehabilitation

$47-04 \quad 12$

A. Health

$47-51 \quad 12$

B. Education

$52-56 \quad 13$

C. Economic empowerment and poverty reduction

$57-59 \quad 14$

D. Return of refugees and internally displaced persons

$60-64 \quad 15$

VII. Coordination of United Nations and donor assistance.

$65-69 \quad 15$

VIII. Conclusion and recommendations

$70-75 \quad 16$ 


\section{Introduction}

1. The present report is submitted in compliance with paragraph 6 of Economic and Social Council resolution 2005/8 on the situation of women and girls in Afghanistan.

2. The report updates information on political, social and economic developments affecting Afghan women since the last report of the Commission dated 22 December 2004 (E/CN.6/2005/5). It draws on information provided, inter alia. by organizations and bodies of the United Nations system ${ }^{\prime}$ and concludes with a set of recommendations.

3. Given the oppression from which Afghan women emerged in late 2001 , the gains they have made in the past few years, including in the legal, political and educational areas, are significant. Progress made in stabilizing Afghanistan's system of governance contributed to the enhancement of women's participation in the political process. Nevertheless, women and girls in Afghanistan remain beset with fornidable security, economic, social and human rights challenges. Afghanistan's first human development report Security with a Human Face. launched by the United Nations Development Programme (UNDP) on 21 February 2005, stresses that generating the means to provide services and jobs and protect human rights, especially in rural areas is one of the main security challenges to the reconstruction process. Using the Gender Development Index (GDI), which combines life expectancy. educational achievements and standard of living indicators. the report shows that Afghan women have one of the lowest GDI indicators in the world. Poverty. illiteracy. limited access to health care and continuous violence against women, call for prompt and effective country-wide action by the Afghan Government and the international community.

\section{Intergovernmental processes}

4. Throughout the reporting period, the situation of women and girls in Afghanistan was examined in various United Nations forums, including the General Assimbly. the Security Council. and two functional commissions of the Economic and Social Council (the Commission on the Status of Women and the Commission on Human Rights).

5. In their discussions of the situation in Afghanistan and its implications for international peace and security. the Security Council and the General Assembly addressed the preparations for the parliamentary and local elections. including the nomination of women candidates, challenges in institution-building, the reform of the justice and security sectors and economic recovery. The related reports of the Secretary-General ${ }^{2}$ stressed that the security situation continued to be of paramount concern. with violence on the increase and the pervasive drug economy posing a significant threat to the long-term security and development of Afghanistan.

6. On 30 November 2006. the General Assembly adopted resolutions 60/32 A and B. in which it applauded the substantive progress achieved in the empowerment of women in Afghan politics. The Assembly reiterated the continued importance of the full and equal participation of women in all spheres of Afghan life. including in the development. recovery and reconstruction programmes. It called for full respect of the human rights and fundamental freedoms of all, without discrimination of any 
kind. including on the basis of gender, ethnicity or religion, in accordance with obligations under the Afghan Constitution and international law, including the Convention on the Elimination of All Forms of Discrimination against Women. It strongly condemned incidents of discrimination and violence against women and girls.

- 7. On 27 October 2005 , on the occasion of the fifth anniversary of the adoption of Security Council resolution 1325 (2000) on women and peace and security. the Council held an open debate on the theme "Women's participation in peace processes". Invited to address the Council, the country director of Women for Women International Afghanistan noted ${ }^{3}$ that significant progress had been made in terms of de jure rights for women and increased political participation. She described the serious challenges, including threats, forced/early marriages and other types of violence facing women in trying to exercise their rights. She emphasized that strengthening of the rule of law and the empowerment of women through capacity-building, education, information sharing and access to resources required the sustained support and attention of the international community.

8. In her report to the General Assembly, ${ }^{4}$ the High Commissioner for Human Rights noted hat the human rights situation in the country remained of great concern. The report called, inter alia. for concrete measures to address the widespread and persistent human rights violations against women and girl children, including forced/early marriages, crimes against the person and discrimination in the justice system.

9. The independent expert of the Commission on Human Rights on the situation - of human rights in Afghanistan reported. ${ }^{5}$ inter alia, violations of women's rights by the State and discrimination related to an array of social practices. He recommended that the Government continue to create comprehensive and sustainable policies to improve the situation of women and children, with special attention to health. education, economic opportunities and political empowerment. and consider women's rights and children's rights in all aspects of policy planning and implementation.

\section{Elections}

10. For the first time since 1988 , on 18 September 2005 , parliamentary elections for the Wolesi Jirga (House of the People), the lower house of the Afghan National Assembly, and provincial council elections were held. The elections had been originally scheduled for June 2004 , in tandem with the presidential vote, but had to be postponed twice for logistical and security reasons. In accordance with the Comstitution. on 24 January 2005. the President of Afghanistan. Hamid Karzai. established the Independent Electoral Commission, consisting of six men and three women, representing different ethnic groups. The Co mmission was assisted by international electoral experts, who together constituted the Joint Electoral Management Body overseeing the organization of the elections. The Joint Electoral Management Body established a Gender Section, which worked closely with departments of the Managing Body active in areas such as public outreach. training and capacity-building. During the electoral process, the Gender Section was mandated to provide support for women candidates. voters and organizations in preparation for the elections. 
11. Despite enhanced security measures, violence was rife during the election campaign. In the south and the east of the country, Taliban forces re-emerged and tried to disrupt the elections for the Wolesi Jirga and the provincial councils, albeit with little success, while in other areas local military commanders attempted to influence election results and intimidated voters and women candidates. Seven parliamentary candidates and six election workers were killed during the two-month campaign prior to election day. Two hundred and eighty-six candidates, including 51 women, voluntarily withdrew their candidacy. ${ }^{6}$ some citing security concerns.

12. Women made up 41.6 per cent of the total 12.5 million voters who registered in 2004 and 2005. Overa II, 43 per cent of the women registered to vote actually cast a ballot. An estimated 6 million of some 12.5 million eligible voters cast their ballots, far fewer than the 8 million voters who had participated in the presidential election in October 2004. A total of 2.753 candidates, 12 per cent of whom were women, stood for election to the Wolesi Jirga for a five-year term.

13. As required under the Constitution. women gained 68 (27 per cent) of the 249 seats in the Wolesi Jirga. In Herat, a woman candidate received the most votes out of 17 candidates. Women also secured 121 ( 29 per cent) out of the 420 seats in the provincial councils. Five provincial seats reserved for women remain vacant owing to the lack of women candidates in three provinces, while women won two provincial council seats in Kabul, in addition to those seats reserved for women.

14. The Afghan Independent Human Rights Commission and the United Nations Assistance Mission in Afghanistan (UNAMA) produced three joint reports on the verification of political rights for the Wolesi Jirga and provincial council elections during the period from 19 April to 13 September. ${ }^{7}$ As far as the types of violations and incidents that constrained the exercise of political rights during the nomination and campaign periods, the reports noted that women candidates had been the target of a number of acts of discrimination, intimidation and violent attacks in some areas. However. this did not prevent the majority of women candidates from undertaking campaign activities nor did it discourage women voters from attending political events and rallies. In many areas. local authorities and police had been particularly responsive to women's security concerns and provided them with guards upon request. A majority of women candidates reported that lack of both financial resources and means of transportation posed serious impediments to their camnaigning activities.

15. A Gender Elections Task Force was established in March 2004 as a subgroup of the Advisory Group on Gender. ${ }^{8}$ The Task Force regrouped in early 2005 to focus on women's participation in the September elections. In March 2005, the Task Force submitted gender-sensitive amendments to the electoral law to the Independent Electoral Commission. In the run up to elections, the Task Force addressed the obstacles facing women candidates campaigning for office as well as the issue of their personal security.

16. To increase women's participation in the elections and ensure their security. - separate polling stations were set up for women. Out of a total 26,243 polling stations throughout Afghanistan, 11,387 were established for women. In some parts of the country, the Afghan national police and army received special training for the elections. To alleviate the security concems of women candidates, voters and civil educators. UNAMA worked with the Ministry of Interior, the Ministry of Women's 
Affairs and chiefs of police in the provinces, alerting them to situations where women have been at risk.

17. The Women's Political Preparatory Committee, established in April 2004 focused on activities promoting women's political participation and women in leadership positions. The Committee was composed of women members of political parties, women members of the Constitutional Loya Jirg a and women from civil society. The Comnittee provided training workshops, manuals and documentation. logistical support and advice. Support and advice to the Committee was provided by the United Nations Development Fund for Women (UNIFEM), the National Democratic Institute for International Affairs, the Friedrich Ebert Foundation and the German Development Service in Afghanistan as well as through German and international development cooperation.

18. In August 2005, the Women's Political Preparatory Committee submitted to the presidential office a list of potential women candidates for the presidential appointees list. Out of a total of 102 seats in the Meshrano Jirga (House of Elders). the upper house of the National Assembly, 34 were appointed by the Pres ident. Half of ihose seats were reserved for women, as stipulated in article 84 of the Constitution. Of the remaining 68 elected members of the Meshrano Jirga, six are women. two of whom hold permanent seats, while the other four hold temporary ones. The total number of women members of the Meshrano Jirga, including the presidential appointees, is 23 , or 22 per cent of the total membership.

\section{Activities of the Ministry of Women's Affairs}

19. During the reporting period, further steps were taken to strengthen the institutional capacity of the Ministry of Women's Affairs and its 34 provincial offices. The Ministry continued to support the Government's policy of advancing the role of women, including by providing assistance and guidance to line ministries in efforts to integrate gender perspectives into their work programmes and budgets. The Ministry also oversaw the implementation of the Convention on the Elimination of All Forms of Discrimination against Women and worked closely with UNAMA and political parties to promote women's political participation and to assist women candidates in the elections.

20. With technical assistance from UNDP and the UNAMA Gender Unit. the Ministry has played a leading role to ensure gender mainstreaming in the follow-up to and implementation of the Millennium Development Goals (MDGs). The Ministry participated actively in consultations with key line ministries on the Afghan MDG targets and indicators to ensure that Afghan women's needs and priorities were taken into consideration. The Ministry also received technical support from UNIFEM in the development of a national action plan for women. framed along the lines of the 12 critical areas of concern of the Beijing Platform for Action. Efforts are under way to ensure that the national action plan for women is endorsed by the Government and integrated into the national development strategy. to be reflected in institutional budgets and implemented by line ministries. The national action plan is currently being finalized.

21. In December 2004, UNAMA and the Ministry signed an implementation agreement for a project entitled "capacity-building of provincial departments of women's affairs". The project covers 15 provinces of Afghanistan. Its aim is to 
contribute to the improved capacity of the Government to respond to the needs of women and girls. Within the framework of the project, one national and three regional workshops on women's political participation were organized prior to the elections and transportation was provided to 10 provincial departments of women's affairs. The project is scheduled for completion in the spring 2006.

22. In April 2005. UNAMA and UNDP assisted the Ministry in drafting recommendations to the Head of the Afghan Civil Service Commission and the Minister of Justice on the proposed civil service law. The recommendations addressed structural disadvantages faced by women in recruitment and hiring processes for senior civil service positions. They also incorporated gender equality provisions in promotions and remuneration policies.

23. With the support of UNDP. the Ministry continued its efforts to institutionalize its gender-training programme by working with the Civil Service Commission to make gender training an integral part of the civil service training. National programmes, such as the national solidarity programme. have also been approached. Throughout the reporting period, a total of 635 staff members fiom different ministries have been trained through the Ministry's inter-ministerial gender training programme.

24. With the assistance of UNIFEM, the Ministry monitors Government action on the implementation of the gender provisions in "The Way Ahead: The Work Plan of the Afghan Government" presented at the Afghanistan Conference in Berlin on 31 March and 1 April 2005. The workplan explicitly set out the Government's commitment to address the needs of women in the economic, health and education sectors and to promote their participation in the civil service.

25. In response to President Karzai's instruction to the Cabinet for giving immediate attention to the nine poorest provinces, Nooristan. Zabul. Panjsher, Daikundi. Badghis. Uruzgan, Paktia, Samangan and Ghor, the Ministry, with the support of UNDP. prepared and carried out a survey in May 2005. assessing the needs and priorities of women in those provinces. The report addressed priorities in four areas: legal status. education. health and economy. As a follow-up. on the instruction of the Cabinet, each ministry was tasked to prepare a workplan for responding to the needs and priorities of women in these provinces.

26. The Ministry continued to coordinate and implement advocacy campaigns on women's rights and violence against women in connection with International Women's Day, 8 March 2005, and the International Day for the Elimination of Violence against Women. 25 November 2005. with the support of United Nations entities, including UNDP.

\section{Violence against women and access to justice}

\section{A. Violence against women}

27. In July 2005. the Special Rapporteur of the Commission on Human Rights on violence against women, carried out a fact-finding mission to Afghanistan. She held meetings with Government officials, members of the judiciary, prosecutors, police officers, doctors and representatives of $n$ on-governmental and international organizations in Kabul, Kandahar and Herat. She also visited prisons and shelters 
for women and received testimonies from women victims of violence. In her press statement of $18 \mathrm{July} 2005$, the Special Rapporteur noted that although considerable change in the legal and institutional framework concerning the situation of women in Afghanistan had occurred in the past three and a half years, violence against women remained dramatic in its intensity and pervasiveness in the public and private spheres of life. In particular, she highlighted widespread forced and child marriages as one of the primary sources of violence against women.

28. The Afghanistan Independent Human Rights Commission estimates that between 60 and 80 per cent of marriages in the country are forced marriages. Many of those marriages, especially in rural areas, involve girls below the age of 15 . Recent reports indicate that child marriages make up more than 40 per cent of all marriages in Afghanistan. ${ }^{4}$ In addition to early and forced marriages, domestic violence, sexual violence. kidnapping. forced seclusion, so-called honour killings and the exchange of girls and women for debt or feud (bad) continued to be a major part of women's and girls' lives in Afghanistan and remained one of the pervasive barriers to women's empowerment and gender equality. The lack of adequate support and responses to women victims of violence has been linked to the high rate of incidents of self-immolation across the country. In Herat alone, there were 75 reported cases of self-immolation during 2005. Women are often discouraged or forbidden from pursuing activities outside the home. Cases of forced prostitution and trafficking among foreign women and Afghan women and children were also reported in 2005 .

29. On 6 June 2005, the Inter-Ministerial Task Force to Eliminate Violence against Women was established by presidential decree. The task force, which is headed by the Ministry of Women's Affairs, is made up of high-level Afghan officials from the Afghan Independent Human Rights Commission, the Supreme Court, the Attorney General's Office, the Ministries of Pilgrimage, Information and Culture, Public Health, Foreign Affairs, Refugees, Interior, and Education and the Afghan Women Judges Association. The task force is mandated to supervise and coordinate action and policy on violence against women at the national level. The task force developed a three-month plan of work, identifying strategies and actions to improve the response of the judicial and law enforcement systems, after which it recommended. inter alia. the training of court officials, and the staff of the Attorney General's Office and police departments on handling cases of violence against women.

30. The UNAMA Human Rights Unit has monitored and investigated cases of violence against women and intervened in situations where women have been at risk and brought them to safe places. The legal department of the Ministry of Women's Affairs, with the support of UNIFEM. has developed a national directory listing agencies and organizations providing support services to women victims of violence.

31. UNIFEM supported the establishment of a consultative group on violence against women, comprising representatives of civil society and Governme nt. to advocate and work for the elimination of violence against women. UNIFEM also provided technical and financial support to civil society organizations promoting women's rights and providing legal services.

32. On 7 February 2005, the Office of the United Nations High Commissioner for - Refugees (UNHCR) signed a partnership agreement with the Afghan Independent 
Human Rights Commission to enhance its returnee monitoring capacity, including monitoring, documenting, reporting and intervening in human rights abuses and violations, including violence against women.

33. Through its women-at-risk programme. UNHCR continued to support Afghan women's non-governmental organizations providing support to women in difficult circumstances and in need of medical, psychological and legal support, including three safe houses or shelters, run by Afghan women's non-governmental organizations (two in Kabul and one in Herat). The women in the shelters are often unaccompanied deportees and women escaping from forced marriages (often with much older men), domestic violence and so-called honour killings. While in many cases, solutions can be found through mediation, family-reunification, intervention of the authorities or legal and psychological counselling, many women have no option but to live in the shelters for prolonged periods. Women residing in the shelters have been offered income generating opportunities following educational and professional training. However, it is difficult for single Afghan women without male family support to live independent lives outside shelters.

34. Serious challenges in addressing issues related to violence against women in Afghanistan remain. The vast majority of cases of violence against women are unreported, and when they are reported there is inadequate or non-existing protection or remedy. Psychosocial support and mental health services to women survivors of violence and harmful traditional practices are very limited. Violence in the private sphere is perceived as a family issue and women and girls who experience violence are either unable or afraid to report the problem to the authorities. If they leave their family environment they risk criminal charges. incarceration and stigmatization from the community. Furthermore, the limited information available indicates that only in very rare cases do perpetrators tace any sanctions. This is illustrated by the absence of criminal charges against those who marry under-age girls in all regions of the country. Therefore, the initiatives by the Government and other actors, including through the Inter-Ministerial Task Force, are of critical importance and should be further supported. strengthened and monitored.

\section{B. Human rights, transitional justice and the rule of law}

35. The Independent Expert of the Commission on Human Rights on the situation of human rights in Afghanistan noted in his report ${ }^{10}$ that there was a justice deficit at almost every level of society in Afghanistan. The report drew attention to the severe limitation to women's access to justice. Discrimination against women in the justice system was also highlighted in the report of the United Nations High Commissioner for Human Rights to the General Assembly. ${ }^{4}$

36. The Ministry of Justice. the Attorney General's Office and the Supreme Court. with the technical advice and support of UNDP and UNAMA, are in the process of finalizing a strategic reform framework for the justice sector entitled "Justice for all". It includes a detailed plan setting out priorities, benchmarks, timelines and costs. It is envisaged that once accomplished, this framework would guide future reform efforts and donor investments. The "Justice for all" policy paper acknowledges the situation of Afghan women who are severely disadvantaged under the existing legal system and calls for concerted action to protect women's rights. It 
further raises concerns with respect to the treatment of women and children under the justice system and recommends that the traditional justice system comply with national laws and international legal standards. The final draft of "Justice for all" was transmitted to the Cabinet in September 2005 for its endorsement.

37. The limited legal qualifications of a majority of judges in Afghanistan has severely affected the quality of decisions being rendered. In effect. this often amounts to denial of justice. Accordingly, the capacity and qualification of the judiciary requires sustained attention. It is critical that attention be paid to the qualification of prospective candidates to the judiciary. It is noted that women still remain grossly underrepresented in the judiciary, making up only 7 per cent of the total number of judges in Afghan courts. The upcoming presidential appointment of Supreme Court judges, which should take place following the inauguration of the Parliament, offers an opportunity for corrective action.

38. UNDP, in close partnership with Afghan judicial institutions, has commenced the implementation of a new "Access to justice" project. aimed at providing information about the justice system to rural communities. The project will include legal awareness programmes and capacity-building for religious and community leaders.

39. The Afghanistan Independent Human Rights Commission's transitional justice programme, aims at the enhancement of respect for human rights and the promotion of national reconciliation. Under this programme. human rights abuses are documented, evidence of violations collected and methods for establishing accountability for past crimes developed through a nation-wide consultation process. Based on the 2005 report of the Commission, "A call for justice". an action plan for peace, justice and reconciliation was developed to implement a national strategy for transitional justice. The strategy includes five elements: acknowledgement of the suffering of the Afghan people; ensuring credible and accountable state institutions; truth-seeking and documentation; promotion of reconciliation; and the establishment of meaningful and effective accountability mechanisms. The action plan did not, however, envisage amnesty for war crimes, crimes against humanity or other gross human rights violations. The action plan was adopted by the Cabinet in December 2005 .

40. The Women's Rights Unit of the Afghan Independent Human Rights Commission has continued to monitor and raise awareness about the promotion and protection of women's human rights, focusing on support to women's active participation in truth-seeking and reconciliation processes.

41. The Government decided to take a comprehensive approach to human rights reporting. The project "Capacity-building for sustained human rights treaty reporting in Afghanistan" was officially launched in Kabul on 27 November 2005. The project will be carried out by the Ministry of Foreign Affairs. in cooperation with other relevant line ministries. It aims at enhancement of the Government's capacity to report on the implementation of human rights treaties to which Afghanistan is party. The project encourages the participation of women's organizations and the collection of gender-sensitive data as part of its database. In April 2005. UNAMA. with the collaboration of UNIFEM and the Ministry of Foreign Affairs held a workshop for civil society organizations on shadow reporting on the Convention on the Elimination of All Forms of Discrimination against Women. The Division for the Advancement of Women of the Department of 
Economic and Social Affairs, is planning a technical assistance mission to Afghanistan in 2006 to provide specific guidance and support on the reporting and implementation of the Convention.

42. The Legal Department of the Ministry of Women's Affairs has provided training for defense attorneys on legal services for women and conducted research on customary practices undermining women's human rights. A mapping exercise has been undertaken to determine whether laws are in line with the Constitution and international legal frameworks. The establishment of family courts throughout the different regions, the setting up of a database on legal cases as a monitoring tool for the efficiency of the justice apparatus in dealing with women's cases and the application of international legal provisions have been encouraged. These activities constitute important contributions to current legal reform initiatives in Afghanistan. The reforms under way must take into account women's legal rights, including under the family and personal status laws.

43. There is continued concern about the situation of women in detention and the issue of illegal detention. The Prison and Detention Centre Law, which was passed on 31 May 2005, stipulated that men and women in detention should be in separate facilities with special attention to women with children. The United Nations Office on Drugs and Crime provided support in drafting the new law and has taken steps to ensure that new premises would be built with due attention to the needs of women, in particular women with children. Where there are no local detention facilities. women accused of crimes have reportedly been placed in "private detention", usually in the house of the head of a village, where they are treated as prisoners and forced to work for the family. There are also reports of women arbitrarily detained when reporting crimes perpetrated against them, for violating social mores and as substitutes for their husbands or male relatives who have been convicted of crimes. ${ }^{4}$ Women and girls have also been detained for "running away", an offence which has no basis in statutory law. These cases often have their roots in forced marriages or violence."

44. The Human Rights Unit of UNAMA has continued to monitor the situation of women in detention and has advocated for the release of women in cases of arbitrary or illegal detention.

45. UNDP, through its Law and Order Trust Fund for Afghanistan, supported the efforts of the Ministry of Interior to rebuild the national civilian police force, including through a project with a special focus on gender issues and women's rights and the recruitment of women police officers. In March 2005, a gender adviser with experience in police organizations commenced work in the Ministry of Interior. The gender adviser developed a departmental gender mainstreaming action plan to support the recruitment, development and promotion of women within the Afghan National Police Force, which, to date, have been carried out with limited success. Among other steps taken to enhance the recruitment of women in the police, a women's residence with facilities for children has been established at the National Police Academy in Kabul.

46. At present, the Afghan National Police Force has only one Family Intervention Uni with an emergency telephone number to receive complaints from women victims of violence. Operated on a pilot basis and under-resourced, it is located in Kabul and staffed by women police officers. It is hoped that similar facilities will open in other regions. 


\section{Social and economic reconstruction and rehabilitation}

\section{A. Health}

47. Health indicators for women in Afghanistan remain unsatisfactory. The maternal mortality ratio, in particular, at 1,600 deaths per 100,000 live births, remains one of the highest in the world. The fertility rate is high, at 6.6 children per woman. Almost half the deaths among Afghan women of reproductive age are the result of complications of pregnancy and childbirth. About 87 per cent of the maternal deaths are preventable. Life expectancy is low; for women it is estimated at 41 years. Estimates indicate that only 40 per cent of the population has access to basic health facilities. The opportunities for psychosocial support are almost nonexistent. According to a 2004 Government report, only 23 per cent of the population has access to safe water and only 12 per cent has access to adequate sanitation. Recent figures on tuberculosis indicate that over 60 per cent of new tuberculosis patients are women.

48. United Nations entities, including the World Health Organization (WHO), the United Nations Children's Fund (UNICEF), the United Nations Population Fund (UNFPA) and UNIFEM, and international non-governmental organizations and donors have increased efforts to support the Government to reduce maternal mortality and provide health services to women. Steps taken include public awareness campaigns, efforts to increase access to health care and health information and the training of women health providers. In the Bamyan and Badakhshan provinces. 50 community midwives are currently being trained, and 20 women in the Takhar and Samangan provinces have received health and hygiene education. After completion of training, these women will reach out with health information to women and girls through house-to-house visits.

49. Technical and policy support has also been provided to the Ministry of Public Health in the establishment of norms and standards for maternal and newborn health care. As a support to training in emergency obstetric care, WHO has, to date, provided 3,000 copies of the manual, "Managing complications in pregnancy and childbirth" in Dari. which has been endorsed by the Ministry of Public Health as the national standard training manual for emergency obstetrics care. WHO is also supporting the Ministry of Public Heatth in introducing measures to improve the family planning programme. A target to eliminate maternal and neonatal tetanus by the end of 2007 has been set and immunization campaigns have continued. UNFPA has worked with the Ministry to set up a Reproductive Health Unit.

50. The United Nations Theme Group on HIV/AIDS. led by UNICEF. is supporting the Government in developing community awareness programmes that improve access to quality HIV/AIDS information and services, with a special focus on at risk groups. including women and girls. The United Nations country team has agreed that one of the priorities of the 2006-2008 United Nations Development Assistance Framework will be the development of a multisectoral approach to HIV/AIDS and sexually transmitted infections, involving the Government and civil society, including community-based organizations, religious leaders and the media. This will include a specific focus on how HIV and AIDS are affecting women and girls. 
51. Enhanced and coordinated efforts are urgently needed to improve women's access to health services, particularly reproductive health services, and to support the Government in meeting its goal of reducing maternal mortality by 25 per cent by 2008. Insecurity and lack of female doctors still prevent many women from seeking health care. Corrective action must address these problems as well.

\section{B. Education}

52. While a significant campaign to increase primary school enrolment has raised the enrolment of girls to almost 40 per cent, compared to 67 per cent for boys, overall school enrolment among girls remains among the lowest in the world, with less than 10 per cent of girls enrolled in secondary school. Dramatic disparities in enrolment between regions and urban and rural areas remain, with girls representing less than 15 per cent of the total enrolment in nine provinces in the east and the south. Schools also continue struggling with high drop-out rates and serious shortages of teachers, especially female teachers. In Uruzgan province, for example. there are no female teachers at all. It is estimated that 86 per cent or approximately 4.85 million women in Afghanistan between the ages 15 and 49 are illiterate. compared to 57 per cent of men. The high illiteracy rate among working age women has numerous adverse effects on domestic health, children's education levels and overall economic development.

- 53. Several United Nations entities, including the United Nations Educational, Scientific and Cultural Organization (UNESCO), UNFPA, UNICEF and the World Food Programme (WFP) have invested in girls' education and women's literacy training as a means of reducing gender disparities and promoting the advancement of women. In its effort to support the education sector. UNICEF has trained more than 50,000 teachers, set up temporary learning spaces, assisted in the development of a new curriculum and provided teaching and learning materials to more than 4.7 million schoolchildren. In June 2004, the Director-General of UNESCO and the Afghan Minister of Education signed an aide-memoire with a focus on capacitybuilding in the areas of teacher training, curriculum reform, technical and vocational education and training and literacy. A strategic action plan for the development of higher education in Afghanistan has also been prepared jointly with the Ministry of Higher Education.

54. Through its school feeding operation, which targets over 1.2 million children, WFP has continued to contribute to the enhancement of children's school attendance. Girls receive an additional take-home ration of vegetable oil as an incentive for families to continue to send girls to school. In areas of acute or chronic food insecurity and/or inaccessible areas, WFP provides a monthly take-home ration of wheat to both girls and boys. To address the shortage of teachers especially in remote areas, WFP provides food support to both in -service teachers and teacher trainees. WFP also implemented 59 non-formal education and literacy training courses in 2005, reaching 18,199 trainees. Vulnerable women such as female heads of houscholds and widows were specifically targeted for these initiatives.

55. The Government and the United Nations country team have established a joint programme on women's integrated functional literacy, under which measurable progress in the literacy rate of women is expected by 2008 . The Government also aims for 100 per cent enrolment as part of the MDG targets for 2015, with girls* 
enrolment at 50 per cent. The Government faces challenges to the achievement of this goal, for example lack of school facilities, in particular girls' schools in rural areas. The challenge is more formidable with regard to girls' secondary schools, which are very few and scattered. Other challenges, such as insecurity, the distance children have to go to get to schools, poverty, lack of female teachers, negative attitudes to girls' education and early marriages remain. Armed factions opposed to the Government have also targeted girls' schools and carried out terrorist attacks such as bombings or burning down schools and campaigning against female education.

56. UNESCO and UNDP are currently engaged in negotiations with the Ministry of Women's Affairs and Kabul University to set up a Women/Gender Studies Institute at the University of Kabul. In addition to its academic and research functions, the Institute will contribute, inter alia, to the policy objectives outlined in the Beijing Platform for Action, the MDGs and Convention on the Elimination of All Forms of Discrimination against Women.

\section{Economic empowerment and poverty reduction}

57. The economic empowerment of women is critical for Afghanistan's sustained recovery, reconstruction and development. The traditional role of women in Afghanistan is, however, a constraint to their equitable participation in economic activities. Female wage labour is still viewed as a solution of last resort for households in desperate straits and their wage rates are normally only half the level of men's. or even less. Women's involvement in the formal sector has mainly been urban-based, mostly as civil servants in the health and education sectors. In agricultural production, women have continued to play an important role. While most of women's labour remains non-remunerative, they make major labour contributions to a number of marketed products such as dried fruits, fuel wood, dairy products and handicrafts. However, even when women's domestic production, such as carpet weaving, forms the main income of the household, they rarely control the marketing of these products. which is most often managed by male relatives or middle men.

58. Several United Nations entities, including the International Labour Organization (ILO), UNDP, WHO, WFP and UNIFEM, and non -governmental organizations have continued to target women within the framework of different income-generation, employment and skills development projects, including the employment service centre project, the recovery and employment Afghanistan programme, the Afghan microfinance for employment project, and the national skills development and market linkages programme. In its training programmes for national staff, ILO provided technical assistance to ensure that gender perspectives were integrated into all aspects of the programmes. In its efforts to promote a rights based approach to economic recovery, ILO has translated and disseminated fundamental labour standards, as well as its "ABC on women workers rights", and has raised awareness about their content in workshops held with workers" and employers' organizations. ILO has also developed a project to promote the re-entry of Afghan women (urban and rural) into the labour market. The Afghan Women's Business Council, supported by UNIFEM, has continued to assist women to market their products. 
59. The Advisory Group on Gender has underlined the need to re -examine national poverty reduction programmes in order to sharpen their focus on women, particularly the economic empowerment of vulnerable groups such as widows, rural women living in remote communities with non-existent economic opportunities and female-headed households, as well as to ensure that constraints faced by wo men in accessing poverty reduction initiatives, including initiatives focused on skills development and employment, are identified and removed. Issues of land and property reform also require particular attention to ensure that the needs and rights

- of vuln erable groups. including households headed by women, are protected.

\section{Return of refugees and internally displaced persons}

60. On 30 August 2005, the accession of Afghanistan to the 1951 Convention relating to the Status of Refugees and its 1967 Protocol, marked a significant step in the country's recovery.

61. Between 1 January and 31 August 2005, a total of 367,694 Afghans were assisted by UNHCR to return to Afghanistan voluntarily, the majority returning from Pakistan (327,809 persons) and the Islamic Republic of Iran $(39,885)$. Of these. 181,276 were girls and women, mainly returning from Pakistan. In addition to assisted returns, there were significant numbers of Afghans returning spontaneously, particularly from the Islamic Republic of Iran, as well as some forcible returns of largely undocumented Afghans. Among those forcibly returned from the Islamic Republic of Iran since the beginning of 2005. were 65 unaccompanied female Afghans.

62. Afghanistan has been challenged by the influx of returnees, a trend that is likely to persist following the successful holding of elections. As a result socio economic investment must be increased in order to boost income generation of the population, especially the most vulnerable groups. As most of the returnees settle in urban areas, there has been an estimated 6 per cent annual growth rate in the urban population.

63. In cooperation with the International Organization for Migration (IOM) and WFP, UNHCR started the organized return of internally displaced pers ons in May 2005, mainly from southern and western Afghanistan. Given the sizeable number of internally displaced persons who, by now, are generating their own income, efforts to enhance self-sufficiency are also reinforced.

64. Shelter continued to be one of the priority requests of returnees. Forty-six per cent of the beneficiaries of shelter projects are women. UNHCR has taken steps to ensure the involvement of women in implementation of the shelter project and projects related to health. water and employment.

\section{Coordination of United Nations and donor assistance}

65. The third annual Afghanistan Development Forum was held in Kabul from 4 to 6 April 2005. with the participation of over 300 delegates from the Government and the international donor community. The Advisory Group on Gender had prepared a background note for the Forum, which drew attention to a number of areas identified by the Ministry of Women's Affairs as key to improving the overall status 
of Afghan women, namely: health, education, legal protection, economic empowerment, eradication of violence against women, and women's participation in politics and public life. The presentations and discussions at the Forum fed into the development of the interim national development strategy, to be presented at an international donors conference in London in January 2006. The national development strategy will integrate follow-up to and implementation of MDGs.

66. The UNAMA Gender Unit continued to support and facilitate gender mainstreaming, including through designated gender focal points in UNAMA s regional offices and close collaboration with the provincial departments of women's affairs. Since 2002, the Unit has been coordinating an information and knowledge -

sharing network for the United Nations country team gender focal points. Early in 2005, UNAMA revitalized the network of gender focal points as an advocacy mechanism and forum for information exchange. Several training activities for both international and national staff were organized and facilitated with a focus on gender awareness and sensitization as part of a mission policy to incorporate gender perspectives into all programmes and operations. Subjects covered included gender mainstreaming, women's rights, standards of conduct and gender and diversity. Assistance and facilitation were also offered to United Nations agencies, on demand. In addition, custom-made trainings were provided to respond to specific mission training needs. The UNAMA Gender Unit also developed a specific gender module for the civil administrators training programme of the Independent Administrative Reform and Civil Service Commission.

67. In June 2005, the UNAMA Gender Unit presented a gender balance action plan to the United Nations Operations Managers Team, which included the goal of collecting sex-disaggregated data on the composition of the national and international staff of United Nations entities.

68. Different United Nations entities and international organizations, including ILO, UNDP, WFP and WHO, have made special efforts for mainstreaming gender in their work in Afghanistan, including in their technical and financial support to line ministries.

69. In August 2005, UNAMA launched a mission-wide information campaign and mandatory staff training programme on prevention of and response to sexual exploitation and abuse and sexual harassment.

\section{Conclusion and recommendations}

70. With the elections to the Wolesi Jirga (House of the People) which resulted in 27 per cent women's representation in national parliament and 29 per cent in the provincial councils, the participation of Afghan women in public life has significantly increased. Among other gains made by women during the transition period following the Bonn talks on Afghanistan in 2001 are the following: greater awareness of gender equality issues within the Government and among the public at large; further steps made to reduce child and maternal mortality; and further steps to improve access to education and literacy of women and girls. The Government has increasingly addressed matters previously considered private, such as violence against women. These changes show that, provided with space and support from outside, Afghan women have 
demonstrated their capacity to engage constructively in public life and to make their contribution to peace and development.

71. Despite these gains, women and girls in Afghanistan face formidable security, human rights, social and economic challenges. The security situation and basic human rights conditions remain poor in many parts of the country, especially outside of Kabul. Armed factions, including the remaining Taliban forces, routinely abuse women's human rights. Many advances by women in the economic, employment and educational spheres are offset by the continuing effects of widespread poverty. Continuing discrimination against women in access to education, health care, land, credits and productive means stifle reconstruction and development efforts.

72. For the post-transitional period, promoting an inclusive, participatory and gender equal society that responds to the aspirations of all Afghan women and men continues to offer the best prospect for improving the overall security and development situation. To date, the steps taken by the Afghan Government, with support and advice from United Nations entities, towards this end are commendable and need to be further strengthened. The major challenge is to build on and sustain positive changes that resulted from the transition. Prompt and effective action on behalf of the Afghan Government, civil society and the international community is needed to promote and protect the human rights of women and girls and to put an end to gender-based discrimination. Economic and social assistance programmes need to build on women's acquired de jure rights, encourage women to participate in the public life and new economic tasks and activities and ensure more gender balance in accessing productive resources and labour markets.

73. To these ends, the Commission on the Status of Women may wish to consider the following recommendations, in addition to those made in previous reports on this subject, most of which are still valid.

74. The Government of Afghanistan should:

(a) Endorse the national action plan on gender equality, in compl iance with the Beijing Platform for Action, and ensure that it is provided with sufficient resources across all sectors and fully implemented in consultation with women's civil society organizations;

(b) Take urgent measures to ensure the protection of ci vilians, in particular women and children;

(c) Strengthen the rule of law and the reform of the justice system, including through training of the judiciary and police; amend or abolish discriminatory laws, regulations, customs and practices; and criminalize violence against women and girls, including domestic violence;

(d) Take specific measures to improve women's access to justice, including through expanding the establishment of family courts and the recruitment and training of women in all Afghan courts;

(e) Develop effective gender-sensitive strategies for investigating allegations of violations of women's human rights and of international humanitarian law, facilitate the provision of remedies to the victims and bring the perpetrators to justice; 
(f) Strengthen measures to prevent and respond to sexual and genderbased violence and develop support services, including health and psychosocial services and the establishment of family intervention units across the country;

(g) Release prisoners held in State detention centres for actions that do not constitute crimes under Afghan law, prohibit the confinement of women in the custody of private individuals, and provide women with adequate support for reintegration in to their communities;

(h) Take resolute action to achieve measurable improvement in the social and economic situation of women and girls in Afghanistan, including through:

(i) Empowering women and girls economically and politically, including through sustainable capacity-building initiatives;

(ii) Supporting fully the equal right of women to work and strengthening efforts to promote their reintegration in employment in all sectors and at all levels of Afghan society;

(iii) Ensuring equal access to land and other productive assets;

(iv) Improving access to health services and health information;

(v) Increasing efforts to reduce and eliminate women's illiteracy; ensuring the full enrolment and retention of girls in primary education, increasing girls' attendance in secondary schools and higher education; training of female teachers; and eliminating discrimination against girls in schools;

(vi) Establishing mechanisms to monitor the progress achieved;

(i) Strengthen efforts to promote and facilitate the full, effective and equal participation of women at all levels and in all spheres of Afghan life, including in decision-making at all levels.

75. The United Nations system, donor Governments and civil society should:

(a) Ensure that the necessary resources are allocated to mainstream gender perspectives into all policies and programmes; that staff have the capacity and necessary tools to support them; and that targeted initiatives aimed at the empowerment of women and girls receive sufficient funding;

(b) Provide technical and financial sup port for reform and the strengthening of the judicial sector, including through merit-based recruitment in order to ensure that qualified women are given equal consideration in the process, training of judicial officers and rehabilitation of infrastructure;

(c) Continue to provide technical expertise and resources to the Ministry of Women's Affairs, line ministries and all governmental bodies in their efforts to mainstream gender and advance the situation of women and girls;

(d) Support sustainable capacity-building for Afghan women, including thrcugh information-sharing, access to resources, education and training, to enable them to participate fully in all societal sectors; women;

(e) Fully support the Government in eradicating violence against 
(f) Ensure that donor actions supporting gender equality and the advancement of women and girls are more harmonized, transparent and collectively effective;

(g) Strengthen efforts to collect sex-disaggregated data across all sectors.

Notes

Information was received from the United Nations Assistance Mission to Afghanistan (UN:AMA), ILO, IOM, OHCHR, UNAIDS, UNDP, UNESCO. UNFPA, UNHCR, UNICEF. UNIFEM, UNODC, UNOPS, WFP, WHO and the World Bank.

$2 \mathrm{~A} / 59 / 744-\mathrm{S} / 2005 / 183$ and $\mathrm{A} / 60 / 224-\mathrm{S} / 2005 / 525$.

${ }^{3}$ S/PV. 5294

$+\mathrm{A} / 60 / 343$

E/CN.4/2005/122

"Thirty-five of the women were running for Provincial Council and 16 for the Wolesi Jirga

${ }^{7}$ Afghan Independent Human Rights Commission-UNAMA Joint Verification of Political Rights

- first report (19 April.3 June 2005); second report (4 June-16 August 2005); third report (17 August-13 September 2005).

${ }^{*}$ Members of the Advisory Group on Gender include UNAMA and other United Nations entities. the Joint Electoral Management Body, donor missions and international and civil society organizations. The Ministry of Women's Affairs holds the secretariat function

"Data from the Inter-Parliamentary Union.

"I"E/CN.4/2005/122

"Amnesty International, Women still under attack -- a systematic failure to protect (London, $2005)$. 